\title{
The theme of the Shoah in the context of institutional education: Teachers, pupils and texts
}

\author{
Milan Mašát \\ Faculty of Education, Palacký University, Czech Republic
}

\begin{abstract}
The paper aims to introduce opportunities for the presentation of the theme of Shoah within institutional education. In the article we deal in detail with the inclusion of a defined phenomenon in the teaching of literary education. The artistic narratives are a suitable standard for familiarizing pupils with the given subject, both in a factual and fantasy, imaginary plane. The paper also deals in more detail with the personality of a teacher of literary education as a primary subject in the interaction between pupils, the text and his subject. The study has a marginal impact on the (not) existence of teacher-oriented research focusing on their views on the implementation of the Shoah theme in school education.
\end{abstract}

Keywords: Shoah; Holocaust; Teacher; Institutional education; Literaty text

Article History: Submitted 8 February 2019; Revised 28 June 2019; Published online 14 August 2019

\section{Introduction}

The issue of Shoah is becoming more and more important in contemporary society. "Jeff Jacoby, the editor of Boston Globe, says that the phenomenon can now be perceived as a warning against the limitation of human rights and freedoms, xenophobia and racism, the control of the media by one party, an individual or a group of persons with common private interests, intolerance and prejudice" (Mašát 2017).

In certain parallel historical sequences and the facts taking place in the present, one of the most important points is why it is necessary to familiarize citizens of democratic societies with the given issue at the youngest age. In our view, it is important for people to be able to recognize a certain deterioration in democratic principles such as the identification, denotation, stigmatization and exclusion of a group of people or a certain minority. Clementina Acedo (2010, p. 2) expresses the following: "In a time of increasing globalization and migration, when many societes have reached unprecendented levels of cultural diversity, resurgent nationalism and xenophobia can remind people of the events that led to the Shoah".

The ability to recognize certain negative aspects associated with a certain degree of totalitarianism should be developed in the context of institutional education ${ }^{2}$. An overview of

Address of Corresponding Author

Mgr. Milan Mašát, Palacký University Olomouc, Faculty of Education, Department of Czech Language and Literature, Žižkovo náměstí 5, 77140 Olomouc, Czech Republic.

$\triangle$ milan.masat01@upol.cz

0000-0001-8602-3059

How to cite: Mašát, M. (2019). The theme of the Shoah in the context of institutional education: Teachers, pupils and texts. Journal of Pedagogical Research, 3(3), 166-172. 
the positives that presents pupils with the presentation of the Shoah ${ }^{3}$ issue can be found on the website United States Memorial Museum: “Understand the roots and ramifications of prejudice, racism, and stereotyping in any society; develop an awareness of the value of pluralism and an acceptence of diversity; think about the use and abuse of power as well as the roles and responsibilities of individuals, organizations, and nations when confronted with civil rights violations and/or policies of genocide..."4 (United States Memorial Museum, Why Teach about the Holocaust?, p. not specified; marked by the author of the paper).

We are of the opinion that the primary intermediaries of the events are teachers. It should be a matter of course that pupils with factual historical facts from the field of Shoah become acquainted with the educational field History, which is based on the presentation of selected key historical phenomena. We believe that there are other educational subjects within which the subject can be presented to pupils. Literary education (Czech Language and Literature) or Civics are the most appropriate. Artistic texts are, in our opinion, a suitable mediator between historical reality and the contemporary world. Implementation of the Shoah theme as much as possible in teaching within institutional education "can make a great contribution if its lessons help to protect human rights, and if they counteract hostility and discrimination along such too-common demarcation as class, disability, ethnicity, faith, gender, and sexual orientation“ (Acedo 2010, p. 1).

\section{Literary Texts}

Literature $^{5}$ offers considerable potential within the defined area. Through arts narration ${ }^{6}$ pupils can develop their imagination, narration has the ability to present various historical facts because "the reality of the Holocaust is the only reason its literature exists, language arts teachers must allow history to drive any literature based-study of the event" (Lindquist 2008, p. 29). Lindquist's statement is developed by Oliveira, who claims that literature can be seen "from (...) perspective that the (educational) power of literature does not lie properly (or at least not solely) in enabling the perception, bringing to presence a world of existing relationships, in which we can say or indicate the geography or the history or the nature the society that is there, let us say, reflected in words and silences" (Oliveira 2017, p. 1174; marked by the author of the paper). With the help of literary texts, such a serious problem ${ }^{7}$ can be imagined for pupils such as a phenomenon Shoah ${ }^{8}$.

There is a considerable amount of intentional literature that is targeted, young ${ }^{9}$ and creative, by its focus, rendering and formal processing. To use literary texts to familiarize pupils with the historical reality of the period "it is necessary to suspend belief at some level if the literature is to be allowed to develop fully" (Lindquist 2008, p. 28).

\footnotetext{
2 Compare: "The education system is the state institution in chargé of the formation of citizens and it is via national memory inculcated in schools that they become members of society and sonform to the social order" (Resnik 2003, p. 300).

3 "Shoah is the Hebrew word for ,catastrophe'. This term specifically means the killing of nearly 6 million Jews in Europe by Nazi Germany and its collaborators during the Second World War. The English-speaking countries more commonly use the word Holocaust, which is Greek for ,sacrifice by fire'." (Mémorial de la Shoah 2017). Compare: "Shoah (...) is the Hebrew term conoting wasteland or destruction" (Kokkola 2003, p. 5).

4 A complete list of phenomena that Shoah's study brings and what a person helps the phenomenon is available on the website of the United States Memorial Museum: https://www.ushmm.org/educators/teaching-about-theholocaust/why-teach-about-the-holocaust.

5 To the theme of Shoah in the context of selected American literature, see Violence, Redemption, and the Shoah (Lang 2008). ${ }^{6}$ According to Jordan (2004, pp. 199 - 200) is literature "one of the best pedagogical tools for educating youngsters about the facts of the Holocaust, for conveying the importance of remembering what happened without explicitly divulging emotionally disturbing information".

${ }^{7}$ Compare: "Literature is an excellent way to understand problems" (Oliveira 2017, p. 1174).

8 Compare: "Reading literature would provide a powerful way of reading history" (Tinberg 2005, pp.73 - 74).

9 Primary texts on which the pupils can learn about certain lines of warfare are the diaries and memories of survivors of the Nazi extermination machine. In European literature, there is a considerable amount of these written testimonies, both of the authors of children or adolescents, with whom the young recipients in our opinion are more identified, which can lead to "the Holocaust - becomes highly personalized" (Jordan 2004, p. 201), and adults. In implementing this area of texts in the teaching of literary education, it is important for the teacher to familiarize pupils with the external and internal aspects of the creation of the selected work.
} 
An essential aspect of the desired text is the selection of literary examples: "When we are considering literature for children, we must inevitably confront question as to whether such a grim topics is at all appropriate for young mind" (Russel 1997, p. 267). The question of the effective removal of certain myths, untruths and half-truths that are traced within the defined subject is expressed by Nicolas Kinloch (2001, p. not specified): “We should teach the Shoah in schools. But I do not think that history teachers will really do so effectively until we have removed from it its quasi mystical aaociations clarifield our own objectives“.

The choice of snippets (or entire books) can fundamentally affect the overall outcome of pupils' text reception. In connotation with our statement it is necessary to mention that "teachers must draw a careful distinction between historical truth and literary truth. Historical truth - the acknowledged factual record regarding a given situation must coexist with literary truth - the establishment of the essence of particular event - while allowing for literary license to be used as a menas of advancing both the story line and the reader's understanding of the situation" (Lindquist 2008, p. 28). Similarly, Kokkola expresses himself (2003, pp. 2 - 3): “Many works contain informing young readers how much of the text is based on evidence and how much on conjecture or imagination, thereby blending traditional history writing with fiction. Such trends are not surprising: teachers are encouraged to use Holocaust literature to complement history teaching".

The fundamental role in the presentation of the defined phenomenon is, in our opinion, the cross-cutting themes that correspond to their expected outputs with the Shoah issues ${ }^{10}$. The actual anchoring of cross-cutting themes into the Framework Educational Programs ${ }^{11}$ is based on the development of general humanity, multicultural, democratic and socio-civic attitudes and values.

At present there is considerable development in the area of intentional literature for children and teenagers on Shoah. Teachers who implement this issue in the teaching of literary education should be consistent critics of artistic narratives. An objective reception and subsequent reflection of texts can lead to the selection of good literature. It is important to realize that the desired educationally effect can be achieved by presenting a smaller number of quality Shoah-literature than by a large number of literature that does not reach sufficient artistic levels.

\section{A Teacher of Literary Education as the Primary Subject of the Presentation of the Shoah Theme to Pupils}

Every teacher who chooses to present the theme of Shoah to pupils is built before deciding what method $^{12}$ the presentation of the defined phenomenon. As indicated above, the teacher has to take

\footnotetext{
10 "We only present some of the benefits of this cross-curricular theme in the field of student attitudes and values [on the basis of the Framework Educational Program for Basic Education]: Personal and Social Education: 'it leads to awareness of the value of the diversity of people, opinions, approaches to problem solving' (Jeřábek 2017, p. 128); Education of a democratic citizen: 'contributes to the formation of values such as justice, freedom, solidarity, tolerance and responsibility, (...) leading to respect for cultural, ethnic and other differences'(p. 130); Education in European and Global Context: 'helps overcome stereotypes and prejudices, (...) creates positive attitudes towards otherness and cultural diversity' (p. 133); Multicultural Education: 'helps to recognize the incompatibility of racial (religious or other) intolerance with the principles of life in a democratic society (...) leads to engagement in combating intolerance, xenophobia, discrimination and racism' (p. 134); Media Education: 'develops sensitivity to prejudices and simplifying judgments about society (particularly minorities) and individuals' (p. 139)" (Mašát 2017).

11 The Framework Educational Programs define within the Czech educational system the curriculum to be given to pupils and determine when to present the prescribed subject matter. It can be said, therefore, that this curriculum defines certain school curricula, under which schools set up School education programs (a compulsory school curriculum document that schools are obliged to observe). The Framework Education Programs are available on the website of the Ministry of Education, Youth and Sports of the Czech Republic: http://www.msmt.cz/.

12 An extensive list of specific methods of teaching Holocaust subjects as well as practical examples is presented $n$ the paper The pedagogical approach to teaching the Holocaust (Imber 2013). A certain method for teachers to get acquainted with pupils with a given phenomenon has been postulated by experts in a seminar Teaching about the Holocaust, which took place in Lithuanian Vilnius in 2000. The detailed enrollment (Grech 2000) is available on the website https://rm.coe.int/1680494240. As part of the Anglo-American methodological approach to the given issue, the socalled integrative approach in the field of mediation of the defined object is currently being developed. See Tinberg \& Weisberger 2014.
} 
into account a considerable number of aspects related to the target group. A specific method of presenting the theme of Shoah to pupils and students brings Lindquist, an assistant professor in the School of Education at Indiana University Purdue Universtiy Fort Wayne, where he teaches courses in social studies, in a paper Defining the Shoah: An Opening Lesson for a Holocaust Unit (2013). Teachers of Literary education (Czech Language and Literature) have their position against teachers of History (if they do not have History as an approved subject) about the fact that if they want to acquaint students with these phenomena, they have to become pupils in the first stage and to study at least elementary facts about the period"13 because "the Shoah's complexity necessitates that teachers establish a well-defined framework as they introduce the topic to their students" (Lindquist 2013, p. 32).

The subsequent phase of the study of Czech language and Literature teachers should be directed towards literary texts, their reception and reflection. At this stage, teachers should be aware that the implicit (model) reader-selected book is not as adult recipients but as a child reader. Based on this, there may be a lot of emotional or reading-based and other experience-based slums. The four possible approaches to how to mitigate the differences between the pupils' past experience and the empirics presented to them are postulated by Martin (2007, pp. 493 - 503): “1) Student Presentations on Holocaust Survivors 2) Documentary Film on the Ghettos and the Camps 3) Student Debates: Why Did This Happen? 4) Did the Shoah Really Happen? Evaluating Sources and Evidence".

In the potential plane, there may be differences between the pedagogues and the presentation object. The fundamental contradictions can be expressed in the personal interest of the educator in the given issue ${ }^{14}$. This thesis is based on the assumption that not all reader-teachers have the same taste, the same area of interest or the same favorite authors. If there is a situation that the given term is anchored in the School Education Program ${ }^{15}$ in the curriculum of the Czech language and Literature, or in the literary part of the curriculum of this educational field, a teacher of literary education is placed before the fact that the Shoah-texts must be included in the classes of literary education. If the teacher does not agree with this subject a prioritis, either the Shoah-themed texts do not mediate or familiarize students with, but in a way that can raise pupils' diametrically different views and feelings than they would have in the desirable qualities and axiological values of the citizens of democratic societies.

David H. Lindquist in the article Complicating Issues in Holocaust Education (2010) postulates the idea that teachers who want pupils to become acquainted with the term Holocaust "must be aware of several unique and potentially troublesome issues that can arise as the Holocaust is presented to students, thus complicating both the teaching of the event. And students'understanding of it" (Lindquist 2010, p. 78).

The teacher of literary education should focus especially on the circle of contemporary literature for children and young people, he should be acquainted with the book titles actively (i.e readership) and should then be able to critically reflect this publication focusing on the target group of readers considering the age of the persons in a given set, their reader abilities, preconceptions ${ }^{17}$ and should also become acquainted with their factual knowledge of the area. Last but not least, teachers should strive for a certain amount of curriculum. To contextualize the preconceptions and issues of Shoah in the area of the presentation of the phenomenon to the

13 Compare: "Teachers who are new to the subject must be willing to invest the time and the energy necessary to developing this expertise, which should be rooted in factual knowledge of the Holocaust history blended with an awareness of the processes involved in being a skilled teacher and historian" (Lindquist 2008, p. 32).

14 See publication Hirsch \& Kacandes 2004.

15 See above. The Framework Educational Program for Basic Education includes the term Holocaust within the curriculum of History. See Jeřábek et al. 2017, p. 56.

${ }^{16} \mathrm{He}$ will not be close to him, his presentation will be unnecessary or identified with the anchoring of the defined issues within his educational field, in the extreme case theoretically could occur a situation where the teacher will not agree with the generally accepted wording of this line of the Second World War.

17 For example, see Pupil's preconceptions as the constitutive component of L1 instruction (Štěpáník \& Slavík 2017, pp. 58 - 80). 
students of Lindquist (2013, p. 32) notes that "teachers should emphasize students'prior knowledge because 'all new knowledge is in some way shaped by our prior knowledge'". In the mentioned case, at least within the curriculum of the subject of History, Czech Language and Literature and Civics.

\section{Implementation of the Shoah Theme into Institutional Education from the Point of View of Teachers}

There is not much research on the views of teachers on the implementation of the Shoah topic in the teaching of an object. Researchers focus mainly on the processes of reception of selected texts by pupils (feelings, factual knowledge, reading literacy and the like ${ }^{18}$ ). Most of the small amount of teacher-oriented research focuses on teachers of History. This fact is not surprising, given the fact that in the educational reality pupils get to know the phenomenon especially within this educational field. Research on teachers of History has brought significant results (for example Moisan \& Hirsch \& Audet 2015; Schär \& Sperisen 2010; Shaer 2017; Drahi 2015). Research that focuses on the views of literary education teachers on the implementation of a defined phenomenon in the teaching of literature is missing (we do not count on research into the selection of texts $\left.{ }^{19}\right)$. We believe that the area has considerable potential, especially in the area of the teacher's fundamental position in teaching. If the teacher is not identified with the theme of Shoah, he/she will not agree to its implementation to the lesson, if he/she misses the knowledge from the scope of intentional literature on Shoah, and for many other reasons, some of which we have suggested above, will not mediate these texts to pupils, in the case where the prescribed curriculum will postulate the presentation of the given term ${ }^{20}$.

We believe that current research, which aims to describe the reality of the use of the Shoah in literary education, should primarily focus on teachers. The results of research focused on literary text (generally) or literary Shoah-text in relation to the pupil are for the development of school didactics or didactics of literature is very beneficial, but it assumes that in the school reality it is taught what is prescribed ${ }^{21}$. And at this point, we see some limits of such research. We believe that it is important first to find out what teachers are really learning, what is part of the prescribed curriculum in what area, what is the material and didactic provision of teaching the given phenomenon, what conditions are provided by out-of-school institutions dealing with the Shoah, and whether they cooperate with schools.

\section{Conclusion}

In the theoretical level, the article presented the possibilities of applying the theme of Shoah in various fields of institutional education with a focus on the teaching of literary education. Artistic narratives are a good standard in which learners can demonstrate various facts related to the subject matter in an accessible way (due to the existence of texts on the theme of Shoah for different age groups of children). In the pedagogical and didactic studies, the role of the teacher as a subject, which is the primary source or mediator of information (in the sphere of literary education, for example in the area of texts offered, in the selection of texts etc.), is greatly

\footnotetext{
18 The most significant researches in this area together with their results are summarized in the paper Literary Education during the Period of Curricular Reform: Recapitulation of Ecucational Concepts and Instructional Quality Analyzing (Jindráček 2018, pp. 42 - 80),

${ }^{19}$ For example Vala 2018.

20 The comparison of the Framework Educational Program for Basic Education and the Israeli Curriculum for a similar degree of institutional education deals with the contribution Representation of Shoa and Holocaust Terms in Selected Curriculum Documents (Mašát 2018) or Representations of Shoah and Holocaust Terms in Selected Curriculum Documents: A Teacher's Perspective (Mašát \& Sladová 2019). Those interested in the genesis of anchor in the Israeli national curriculum with teacher measurements refer to the contribution Teacher autonomy within a flexible national curriculum: development of Shoah (holocaust) education in Izraeli state school (Cohen 2016) or the article The international status of education about the holocaust (Carrier et al. 2015).

${ }^{21}$ See Framework Education Program for Elementary Education.
} 
appreciated. We believe that current pedagogical and didactic research should focus primarily on the personality of the teacher, who is the primary subject of influencing the integration and presentation of certain topics to pupils. Comprehensive descriptions in the field may yield results that can be used to determine how to positively influence the implementation of the Shoah theme in literary education.

\section{References}

Acedo, C. (2010). Lessons from the Shoah for history, memory, and human rights. Prospect, 40, 1 - 3.

Carrier, P., Fuchs, E., \& Messinger, T. (2015). The international status of education about the holocaust: A global mapping of textbooks and curricula. Paris, France: UNESCO Publishing.

Cohen, E., H. (2016). Teacher autonomy within a flexible national curriculum: development of Shoah (holocaust) education in Izraeli state school. Curriculum Studies, 48(2), 167 - 191.

Drahi, P. (2015). L'expérience de l'enseignement de la Shoah en France par des professeurs de collège et de lycée: un analyseur de l'expertise professionnelle face à une question socialement vive (Disertační práce). Retrieved 22 September 2018, from http:// www.theses.fr/2015PA100077.

Grech, L. (2000). Teaching about the Holocaust. Strasbourg: Council for Cultural Co-operation. Retrieved 1 June 2018, from https://rm.coe.int/1680494240.

Hirsch, M. \& Kascandes, I. (2004). Teaching the Representation of the Holocaust. New York: Modern Language Assn.

Imber, S. (2013). The pedagogical approach to teaching the Holocaust. Teaching history 47(3), 21 - 24.Available

Jeřábek, J. et al. (2017). Rámcový vzdělávací program pro základní vzdělávání (Framework Education Program for Elementary Education). Retrieved 14 June 2018, from http://msmt.cz/vzdelavani/zakladnivzdelavani/učební-dokumenty.

Jindráček, V. (2018). Literary education during the period of curricular reform: recapitulation of ecucational concepts and instructional quality analyzing. Paidagogos 2018(1 - 2), $42-80$.

Jordan, S., D. (2004). Educating without overwhelming: authorial strategies in children's holocaust literature. Children's Literature in Education 35(3), 199 - 218.

Kinloch, N. (2001). Parallel catastrophes? Uniqueness, redemption and the Shoah. Teaching history, 104, 8 14.

Kokkola, L. (2003). Representing the Holocaust in Children's Literature. New York: Routledge.

Lang, J. (2008). Violence, Redemption, and the Shoah. Studies in American Jewish Literature, 27, 69 - 86.

Lindquist, D., H. (2010). Complicating Issues in Holocaust Education. Journal of Social Studies Research 34(1), $77-93$.

Lindquist, D., H. (2013). Defining the Shoah: An Opening Lesson for a Holocaust Unit. The Social Studies, $104(1), 32-37$.

Lindquist, D., H. (2008). Developing Holocaust Curricula: The Content Decision-Making Process. A Journal of Educational Strategies, Issues and Ideas, 82(1), 27 - 34.

Martin, C., K. (2007). Teaching the Shoah: Four approaches that draw students in. The History Teacher, 40(4), $493-503$.

Mašát, M. (2017). To the Utilization of the Shoah theme in the reading-books for the second grade of primary schools. Jazyk - literatura - komunikace 2017(2), 68 - 78.

Mašát, M. (2018). Representation of Shoa and holocaust terms in selected curriculum documents. Proceedings of the International Scientific Conference for Ph.D. students and assistants - QUAERE 2018 8(8), 802 - 809.

Mašát, M. \& Sladová, J. (2019). Representations of Shoah and Holocaust Terms in Selected Curriculum Documents: A Teacher's Perspective. Universal Journal of Educational Research, 7(2), 457 - 462.

Mémorial de la Shoah. (2017). What is the Shoah? Mémorial de la Shoah. Retrieved 14 June 2018, from http://www.memorialdelashoah.org/.

Moisan, Sabrina \& Hirsch, Sivane \& Audet, Geneviève. (2015). Holocaust education in Quebec: Teachers' Positioning and Practises. McGill Journal of Education 50(2-3), 247 - 268.

Oliveira, W. M. (2017). In search of over there: education, space, and language. Educação \& Realidade 42(3), 1161-1182.

Resnik, J. (2003). 'Sites of memory'of the Holocaust: shaping national memory. The education system in Israel. Nations and Nationalism 9(2), 297 - 317. 
Russel, D. L. (1997). Reading the Shards and Fragnments: Holocaust Literature for Young Readers. The Lion and the Unicorn, 21(2), $267-280$.

Schär, B. C. \& Sperisen, V. (2010) Switzerland and the Holocaust: teaching contested history. Journal of Curriculum Studies 42(5), 649 - 669.

Shaer, M. (2017). The Holocaust's Great Escape. Smithsonian magazine. Retrieved 12 July 2018, from https:// www.smithsonianmag.com/history/holocaust-great-escape-180962120/.

Štěpáník S. \& Slavík, J. (2017). Pupil's preconceptions as the constitutive component of L1 instruction. Pedagogická orientace, 21(1), 58 - 80.

Tinberg, H. (2005). Taking (and teaching) the shoah personally. College English, 68(1), 72 - 89.

Tinberg, H. \& Weisberger, R. (2014). Teaching History: Teaching the Holocaust. An integrative approach. Bloomington: Indiana University Press.

United States Memorial Museum. (2019). Why Teach about the Holocaust? Retrieved 14 June 2018, from https://www.ushmm.org/educators/teaching-about-the-holocaust/why-teach-about-the-holocaust.

Vala, J. (2018). Co (ne)číst v literární výchově v 9. ročníku ZŠ. Komenský, 143(1), 19 - 24. 